\title{
Distribution and seasonal variability of trace elements in atmospheric particulate in the Venice Lagoon
}

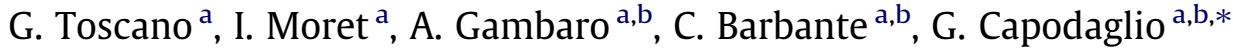 \\ a DAIS, Università Ca' Foscari, Venezia, Italy \\ ${ }^{\mathrm{b}}$ Istituto per la Dinamica dei Processi Ambientali (CNR-IDPA), Venezia, Italy
}

\section{A R T I C L E I N F O}

\section{Article history:}

Received 4 July 2011

Received in revised form 6 September 2011

Accepted 8 September 2011

Available online 22 October 2011

\section{Keywords:}

Trace elements

Aerosol

Venice Lagoon

Size distribution

Inductively coupled quadrupole mass

spectroscopy

\begin{abstract}
A B S T R A C T
Size distribution and selected element concentrations of atmospheric particulate matter (PM) were investigated in the Venice Lagoon, at three sites characterised by different anthropogenic influence. The $\mathrm{PM}_{10}$ samples were collected in six size fractions (10-7.2, 7.2-3.0, 3.0-1.5, 1.5-0.95; 0.95-0.49 and $<0.49 \mu \mathrm{m}$ ) with high volume cascade impactors, and the concentration of 17 elements ( $\mathrm{Al}, \mathrm{As}, \mathrm{Ca}$, $\mathrm{Cd}, \mathrm{Co}, \mathrm{Cu}, \mathrm{Fe}, \mathrm{K}, \mathrm{Li}, \mathrm{Mg}, \mathrm{Mn}, \mathrm{Na}, \mathrm{Ni}, \mathrm{Pb}, \mathrm{Sr}, \mathrm{V}, \mathrm{Zn}$ ) was determined by inductively coupled plasma quadrupole mass spectroscopy. More than 1 year of sampling activities allowed the examination of seasonal variability in size distribution of atmospheric particulates and element contents for each site.

At all the stations, particles with an aerodynamic diameter $<3 \mu \mathrm{m}$ were predominant, thus accounting for more than $78 \%$ of the total aerosol mass concentration. The highest $\mathrm{PM}_{10}$ concentrations for almost all elements were found at the site which is more influenced by industrial and urban emissions. Similarity in size distribution of elements at all sites allowed the identification of three main behavioural types: (a) elements found mainly within coarse particles ( $\mathrm{Ca}, \mathrm{Mg}, \mathrm{Na}, \mathrm{Sr}$ ); (b) elements found mainly within fine particles (As, $\mathrm{Cd}, \mathrm{Ni}, \mathrm{Pb}, \mathrm{V}$ ) and (c) elements with several modes spread throughout the entire size range (Co, $\mathrm{Cu}, \mathrm{Fe}, \mathrm{K}, \mathrm{Zn}, \mathrm{Mn}$ ).

Factor Analysis was performed on aerosol data separately identified as fine and coarse types in order to examine the relationships between the inorganic elements and to identify their origin. Multivariate statistical analysis and assessment of similarity in the size distribution led to similar conclusions on the sources.
\end{abstract}

(c) 2011 Elsevier Ltd. All rights reserved.

\section{Introduction}

Epidemiological studies worldwide have indicated a strict relationship between airborne particulate matter (PM) and detrimental effects on human health (Pope, 1996; Schwartz et al., 1996). The percentage of matter inhaled through the respiratory tract as well as the degree of toxicity depend on the particle size; indeed, the chemical composition, which varies significantly in connection with particle size, regulates the toxicity of any specific element. Several studies have indicated the water-soluble metal content as a possible harmful component of airborne PM, and transition metals such as $\mathrm{Cu}, \mathrm{Fe}$, and $\mathrm{Zn}$, associated with aerosol, have been hypothesised to cause cellular inflammation, as they mediate the release of free radicals in lung fluids (Donaldson et al., 1997). Moreover, different sources emit PM with different size distribution, which are deposited at different rates. Particles with diameters in the range of $0.1-1.0 \mu \mathrm{m}$ (accumulation mode) deposit

\footnotetext{
* Corresponding author at: DAIS, Università Ca' Foscari, Venezia, Italy. Fax: +39 0412348549.
}

E-mail address: capoda@unive.it (G. Capodaglio). slowly and can be transported far from emission sources with effects on remote areas (Allen et al., 2001).

A bimodal distribution of atmospheric particulates has been reported for many urban sites (Chan et al., 2000; Karanasiou et al., 2007). The coarse particles (aerodynamic diameter $>3 \mu \mathrm{m}$ ) are usually formed by mechanical action at high temperatures, crustal erosion, road dust resuspension and sea salts, being the fine fraction a mixture of primary and secondary aerosol, principally emitted from anthropogenic sources (combustion, high-temperature industrial activities, automotive traffic, etc.). Therefore, detailed information on the aerosol mass distribution and on its chemical composition is essential to identify their sources as well as to assess the environmental and health risks. Improvements in analytical techniques, together with the increase in awareness of ultraclean procedures have drawn on reliable information about trace element concentrations in the different size ranges of airborne particles. As trace element contents in aerosol can frequently be associated with specific anthropogenic sources, the trace metals may be used as tracers in order to identify the source of atmospheric PM (Weckwerth, 2001; Birmili et al., 2006). 
The Lagoon of Venice is a complex system situated in the northeast of Italy between the Adriatic Sea and a heavily industrialised and densely populated mainland (the urban area's inhabitants are more than 300000). Numerous local anthropogenic sources contribute to contaminate Lagoon atmosphere, particularly thermoelectric, petrochemical and incineration plants in the large industrial zone of Porto Marghera, glass factories, vehicular traffic, intense commercial and tourist harbours as well as airport traffic are involved in the process.

In the framework of a study, that was carried out to define the quality of the atmosphere of the Venice Lagoon, the size distributions of particulate matter and the element concentrations in atmospheric aerosol were investigated at three sites characterised by aerosol of different origin. Of these three sites, one was mainly affected by aerosol of marine origin and associated with long range transport, another one by aerosol of industrial and urban sources and the last one was affected by urban and vehicular traffic. Here, we report the results obtained for each site by the analysis of samples, which have been collected for more than 1 year with the aim of examining seasonal variability of particulate matter and its element size distribution. In order to study the differences observed in the relevant size distributions to the selected elements, factor analysis was performed separately on fine and coarse aerosol data. The examination of the relationship between the different inorganic elements actually helps in identifying the principal emission sources at the different stations.

\section{Materials and methods}

Aerosol sampling was conducted from March 2002 to July 2003 at three sites in the Venice Lagoon (Fig. 1): site 1 (lat. $45^{\circ} 25^{\prime} 38.5^{\prime \prime} \mathrm{N}$, long. $12^{\circ} 12^{\prime} 47.6^{\prime \prime} \mathrm{E}$ ), located downwind from the Porto Marghera industrial area and influenced by industrial and urban aerosol sources; site 2 (lat. $45^{\circ} 25^{\prime} 21.8^{\prime \prime} \mathrm{N}$, long. $12^{\circ} 26^{\prime} 12.2^{\prime \prime} \mathrm{E}$ ), affected by marine aerosol and long range sources; and site 3 (lat. $45^{\circ} 29^{\prime} 37.9^{\prime \prime} \mathrm{N}$, long $12^{\circ} 19^{\prime} 27.2^{\prime \prime} \mathrm{E}$ ) located downwind from a mainland urban area, close to Venice Airport and highway A27. Sixteen samples were collected at site 2, eleven at site 1 and 5 at site 3 ; they were then split into two groups based on season characteristics: October-March (cold season) and April-September (warm season).

Atmospheric PM sampling was performed by high volume sixstage cascade impactors (Tisch Inc.) with cut-offs for the aerodynamic particle sizes in $\mu \mathrm{m}$ : 10-7.2, 7.2-3.0, 3.0-1.5, 1.5-0.95, $0.95-0.49$ and $<0.49$ (flux of $1.13 \mathrm{~m}^{3} \mathrm{~min}^{-1}$ ). Samples were collected when the wind blew from selected quadrants: southeast

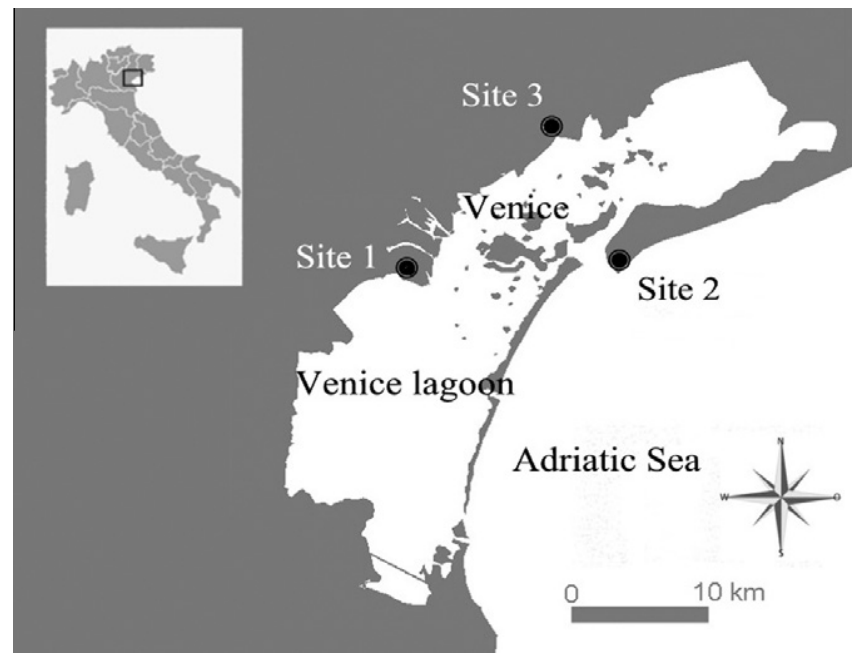

Fig. 1. Sampling sites at the Venice Lagoon. at site 2, northeast at sites 1 and 3. A more comprehensive description of the sampling sites and the strategy was previously reported (Gambaro et al., 2004; Manodori et al., 2006).

The preparation of the material, which was previously described, was carried out under a laminar flow clean area (class 100). In short, filters were conditioned for $24 \mathrm{~h}$ at a temperature of $20^{\circ} \pm 5^{\circ} \mathrm{C}$ and a relative humidity of $30 \pm 5 \%$ and weighted with $0.01 \mathrm{mg}$ precision.

The analytical procedure was previously described in detail, and is presented here only in short, some more details are reported on the supplementary file for analytical methodology (Toscano et al., 2009).

The samples were digested by a microwave oven (Milestone, Ethos 1600) in $100 \mathrm{ml}$ tetrafluoromethoxyl vessels. The digestion mixture was composed of $\mathrm{HNO}_{3}, \mathrm{H}_{2} \mathrm{O}$ and $\mathrm{HF}$ at a ratio of $5: 1.5: 1$; all the reagents were ultra-pure grade (Romil Ltd., Cambridge).

$\mathrm{Al}, \mathrm{As}, \mathrm{Ca}, \mathrm{Cd}, \mathrm{Co}, \mathrm{Cu}, \mathrm{Fe}, \mathrm{K}, \mathrm{Li}, \mathrm{Mg}, \mathrm{Mn}, \mathrm{Na}, \mathrm{Ni}, \mathrm{Pb}, \mathrm{Sr}, \mathrm{V}$ and $\mathrm{Zn}$ were determined by inductively coupled quadrupole mass spectroscopy (Agilent model 7500). Quantification was carried out by a matrix-matched calibration curve, with 11 points to cover the entire concentration range of elements in the aerosol samples (Toscano et al., 2009).

Blank concentrations for the slotted membranes and the back filters, including the contribution from filter handling during sampling, were measured and used to correct the concentrations measured in the dissolved filters. The blank metal contents as $\mu \mathrm{g} /$ filter for the slotted membrane and the back filter are reported in the Supplementary Table A. The blank contribution to the total concentration was regularly under $20 \%$ for all the elements, only for arsenic and litium in samples collected in the site 2 and 3 blank frequently represented more than $50 \%$ of the total content, therefore element concentrations were under the detection limit so that such elements were excluded from the multivariate statistical analysis. In order to assess the significance of data, which have been separately identified as fine and coarse particles data, the LODs in term of $\mathrm{ng} \mathrm{m}^{-3}$ were calculated as three times the SD for the blank concentration for the two classes (Supplementary Table A).

Accuracy and precision (repeatability) were measured using Standard Urban Dust Reference Material (NIST, SRM-1648) following the procedure reported in supplementary analytical methodology. The minimum recovery value was $80 \%$ for $\mathrm{K}$ and the maximum was $120 \%$ for Zn (Supplementary Table B).

\section{Results and discussion}

\subsection{Particle mass concentration and size distribution}

The $\mathrm{PM}_{10}$ mass concentration measurements taken from March 2002 to June 2003 and separately identified as cold and warm season data at the three stations ranged from some units to some tens of $\mu \mathrm{g} \mathrm{m}^{-3}$ (see Supplementary data in Table C), The values are consistent with the concentrations detected in many European cities (Heal et al., 2005; Hueglin et al., 2005; Viana et al., 2007; Pey et al., 2009; Makkonen et al., 2010; Vercauteren et al., 2011). The statistical tests did not show differences (at the 0.05 level) between the two season groups for sites 1 and 2. Site 3 showed a similar behaviour, however no statistical evaluation was possible because of the reduced number of samples collected during the warm season.

The general particulate distribution in the three sites in the warm and in the cold seasons was bimodal, registering the highest abundance in the $0.49-1.5 \mu \mathrm{m}$ fraction and a relative maximum for the particulates with an aerodynamic diameter $>3 \mu \mathrm{m}$ (see Supplementary Fig. A). Only at site 3 a unimodal distribution with a maximum of the fine particulates was observed during the cold 
Table 1

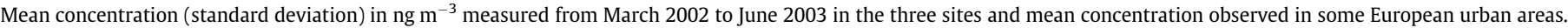

\begin{tabular}{|c|c|c|c|c|c|c|c|c|c|c|c|c|c|c|c|c|c|}
\hline & $\mathrm{Al}^{\mathrm{a}}$ & As & $\mathrm{Ca}^{\mathrm{a}}$ & $\mathrm{Cd}$ & Co & $\mathrm{Cu}$ & $\mathrm{Fe}^{\mathrm{a}}$ & $\mathrm{K}^{\mathrm{a}}$ & $\mathrm{Li}$ & $\mathrm{Mg}^{\mathrm{a}}$ & Mn & $\mathrm{Na}^{\mathrm{a}}$ & $\mathrm{Ni}$ & $\mathrm{Pb}$ & $\mathrm{Sr}$ & V & $\mathrm{Zn}^{\mathrm{a}}$ \\
\hline Site 1 & $\begin{array}{l}0.4 \\
(0.2)\end{array}$ & $\begin{array}{l}3 \\
(2)\end{array}$ & $\begin{array}{l}0.7 \\
(0.4)\end{array}$ & $\begin{array}{l}2 \\
(2)\end{array}$ & $\begin{array}{l}0.3 \\
(0.1)\end{array}$ & $\begin{array}{l}10 \\
(6)\end{array}$ & $\begin{array}{l}0.4 \\
(0.2)\end{array}$ & $\begin{array}{l}0.2 \\
(0.1)\end{array}$ & $\begin{array}{l}0.5 \\
(0.1)\end{array}$ & $\begin{array}{l}0.2 \\
(0.1)\end{array}$ & $\begin{array}{l}16 \\
(8)\end{array}$ & $\begin{array}{l}0.37 \\
(0.05)\end{array}$ & $\begin{array}{l}14 \\
(5)\end{array}$ & $\begin{array}{l}19 \\
(10)\end{array}$ & $\begin{array}{l}2 \\
(1)\end{array}$ & $\begin{array}{l}12 \\
(3)\end{array}$ & $\begin{array}{l}0.06 \\
(0.06)\end{array}$ \\
\hline Site 2 & $\begin{array}{l}0.13 \\
(0.05)\end{array}$ & Udl & $\begin{array}{l}0.16 \\
(0.09)\end{array}$ & $\begin{array}{l}0.6 \\
(0.8)\end{array}$ & $\begin{array}{l}0.06 \\
(0.04)\end{array}$ & $\begin{array}{l}4 \\
(1)\end{array}$ & $\begin{array}{l}0.14 \\
(0.05)\end{array}$ & $\begin{array}{l}0.13 \\
(0.06)\end{array}$ & $\begin{array}{l}0.11 \\
(0.05)\end{array}$ & $\begin{array}{l}0.10 \\
(0.03)\end{array}$ & $\begin{array}{l}5 \\
(2)\end{array}$ & $\begin{array}{l}0.5 \\
(0.2)\end{array}$ & $\begin{array}{l}3 \\
(1)\end{array}$ & $\begin{array}{l}10 \\
(3)\end{array}$ & $\begin{array}{l}1.1 \\
(0.5)\end{array}$ & $\begin{array}{l}5 \\
(2)\end{array}$ & $\begin{array}{l}0.03 \\
(0.02)\end{array}$ \\
\hline Site 3 & $\begin{array}{l}0.11 \\
(0.05)\end{array}$ & $\begin{array}{l}6 \\
(5)\end{array}$ & $\begin{array}{l}0.3 \\
(0.1)\end{array}$ & $\begin{array}{l}3 \\
(3)\end{array}$ & $\begin{array}{l}0.09 \\
(0.04)\end{array}$ & $\begin{array}{l}9 \\
(5)\end{array}$ & $\begin{array}{l}0.2 \\
(0.1)\end{array}$ & $\begin{array}{l}0.2 \\
(0.1)\end{array}$ & $\begin{array}{l}0.10 \\
(0.01)\end{array}$ & $\begin{array}{l}0.10 \\
(0.04)\end{array}$ & $\begin{array}{l}7 \\
(3)\end{array}$ & $\begin{array}{l}0.20 \\
(0.07)\end{array}$ & $\begin{array}{l}2 \\
(1)\end{array}$ & $\begin{array}{l}18 \\
(9)\end{array}$ & $\begin{array}{l}1.0 \\
(0.4)\end{array}$ & $\begin{array}{l}2 \\
(1)\end{array}$ & $\begin{array}{l}0.05 \\
(0.04)\end{array}$ \\
\hline Flanders $^{\mathrm{b}}$ & 0.16 & 3.8 & 0.43 & & & 14 & 0.73 & 0.24 & & 0.10 & 8.9 & 0.88 & 3.6 & 21 & & 7.6 & 0.067 \\
\hline S-E Finland ${ }^{\mathrm{c}}$ & 0.25 & 0.85 & & 0.31 & 0.13 & 2.6 & 0.27 & & & & 7.3 & & 1.3 & 13 & & 2.7 & 0.020 \\
\hline Stockholm $^{\mathrm{d}}$ & & 0.88 & & 0.11 & 0.15 & 7.7 & & & & & 5.5 & & 2.3 & 3.4 & & 1.6 & 0.017 \\
\hline Barcellona ${ }^{\mathrm{e}}$ & & 0.38 & & 0.18 & 0.45 & 37 & & 0.3 & 0.28 & 0.4 & 4.3 & 1.7 & 3.2 & 6.6 & 3.2 & 6.2 & 0.046 \\
\hline Birmingham ${ }^{\mathrm{f}, *}$ & 0.53 & & & 0.21 & 0.08 & 10 & 0.09 & & & & 4.0 & & 0.93 & 9.6 & & & 0.033 \\
\hline Edinburgh $^{g}$ & & 0.37 & & 0.34 & & 4.9 & 0.18 & & & & 2.9 & & 3.4 & 14 & & 1.1 & 0.013 \\
\hline Swiss urban areas ${ }^{\mathrm{h}}$ & 0.103 & 0.54 & 0.41 & 0.27 & & 31 & 0.77 & 0.23 & & 0.06 & 10 & 0.38 & 2.2 & 26 & & 1.3 & \\
\hline
\end{tabular}

$\mathrm{Udl}=$ under detection limit.

a $\mu \mathrm{g} \mathrm{m}^{-3}$.

b Vercauteren et al., 2011.

c Makkonen et al., 2010.

d Johansson et al., 2009.

e Pey et al., 2009.

f Birmili et al., 2006.

${ }^{*} \mathrm{PM}_{7.5}$ metal concentration.

g Heal et al., 2005.

h Hueglin et al., 2005.

season. The particles with an aerodynamic diameter $<1.5 \mu \mathrm{m}$ were more than $70 \%$ of the $\mathrm{PM}_{10}$, with the coarse fraction ( $>3 \mu \mathrm{m}$ ) ranging between $18 \%$ (site 3 ) and $22 \%$ of the $\mathrm{PM}_{10}$ (sites 1 and 2 ). These results are generally in tune with literature data for urban and industrial areas (Chan et al.,1997, 2000; Manoli et al., 2002; Heal et al., 2005; Karanasiou et al., 2007).

\subsection{Element concentrations and seasonal variability}

The element $\mathrm{PM}_{10}$ mean concentrations are reported in Table 1. The values detected at site 1 and site 3 were similar and in line with those reported for urban-industrial areas in Northern and Central Europe, mean concentrations detected in some European urban areas are reported in Table 1 (Heal et al., 2005; Hueglin et al., 2005; Birmili et al., 2006; Viana et al., 2007; Johansson et al., 2009; Pey et al., 2009; Makkonen et al., 2010; Vercauteren et al., 2011). The highest metal concentrations for almost all elements (either typical crustal or anthropogenic) was found at site 1 , which is located downwind from the industrial zone of Porto Marghera and affected by urban emissions. Petrochemical production and refining, waste incinerators, or thermal-electric plants (fed by fossil fuels) are the main industrial activities. Moreover, a non-ferrous metal industry as well as glass factories are active in this area ("Rapporto ambientale d'area di Porto Marghera, Bilancio Ambientale", 1998-2007).

Gypsum landfill activities and relevant building works to renovate plants could account for the high $\mathrm{PM}_{10}$ concentrations of typical crustal elements ( $\mathrm{Al}, \mathrm{Fe}$, and Ca particularly).

The high concentrations and the size distribution of $\mathrm{V}, \mathrm{Ni}$, As and $\mathrm{Cd}$ can be related to electric power plants in the industrial zone. It is known that the combustion of coal is an important source of As and oil combustion is a significant source of $\mathrm{V}$ and $\mathrm{Ni}$, being the non-ferrous metal industry accountable for emissions of $\mathrm{As}, \mathrm{Cd}, \mathrm{Cu}, \mathrm{Pb}$ and $\mathrm{Zn}$ (Nriagu and Pacyna, 1988; Pacyna and Pacyna, 2001).

The average concentrations of $\mathrm{Cd}$ and As at sites 1 and 3 were higher - sometimes up to threefold - than those reported by many literature data, (Heal et al., 2005; Moreno et al., 2006; Salma et al., 2002). However, the data reported are in line with those obtained by different studies conducted in the Venice Lagoon (Mantovan et al., 2004; Gambaro et al., 2007; Rampazzo et al., 2008).
Arsenic is present in the environment of the Veneto region, its concentration in soils being currently above the regulatory threshold $\left(20 \mathrm{mg} \mathrm{kg}^{-1}\right)$. The high concentration of As in soils is due to rock composition as well as to human activities; volcanic and mine areas contribute to naturally high As concentrations, while the fossil fuels, the agrochemical applications, the smelting and glass factories are the main anthropogenic As sources (Bini, 2008).

Table 2 reports the mean $\mathrm{PM}_{10}$ and element concentrations separately defined as fine and coarse fractions as they have been measured in the warm and in the cold seasons. Significant season differences were observed in the fine fraction at site 2 for $\mathrm{Ni}, \mathrm{Cu}$, $\mathrm{Zn}$ and $\mathrm{Pb}$ (at the 0.05 level). Site 3 showed similar behaviour; the concentrations of $\mathrm{Ni}, \mathrm{Cu}, \mathrm{Zn}, \mathrm{Cd}, \mathrm{Pb}$ and As determined in the cold season were almost double than those determined in the warm season. However, because of the small amount of data, no statistical evaluation was possible at this station. A higher concentration of anthropogenic elements in the cold season has been regularly observed in urban regions (Lee et al., 1994; Voutsa et al. 2002), this can be ascribed to higher emissions from the combustion of fossil fuels and to the frequent and persistent thermal inversions at ground level of the Po Valley during the cold season (Marcazzan et al., 2001).

\subsection{Seasonal element size distributions}

On the basis of the size distributions (Fig. 2 and Supplementary Fig. B), elements could be roughly divided into three main groups: (a) elements, showing a large mode in the coarse fraction (3$10 \mu \mathrm{m}$ ), (b) elements showing a large mode in the very fine fraction $(0.49-1.5 \mu \mathrm{m})$ and $(\mathrm{c})$ elements presenting several modes spread throughout the size distribution. This behaviour is generally in line with the findings reported by other authors (Wang et al., 2006; Karanasiou et al., 2007); however, the size distribution of some elements was different as regards the three sites and the two seasonal groups.

\subsubsection{Elements ( $\mathrm{Na}, \mathrm{Mg}, \mathrm{Sr}, \mathrm{Ca}$ )}

The distribution of $\mathrm{Na}, \mathrm{Mg}, \mathrm{Sr}$ and Ca showed a large mode in the coarse fraction $(3-10 \mu \mathrm{m})$ in all stations, indicating that they are mainly originated from natural sources. Their percentages in the coarse fraction ranged from $71 \%(\mathrm{Na})$ to $57 \%(\mathrm{Sr})$ at site 2 , 
Table 2

Mean concentration of PM $\left(\mu \mathrm{g} \mathrm{m}^{-3}\right)$ and elements $\left(\mathrm{ng} \mathrm{m}^{-3}\right)$ in the fine $\left(\mathrm{PM}_{3}\right)$ and corse fractions $\left(\mathrm{PM}_{3-10}\right)$ during warm and cold seasons.

\begin{tabular}{|c|c|c|c|c|c|c|c|c|c|c|c|c|}
\hline & \multicolumn{4}{|l|}{ Site 1} & \multicolumn{4}{|l|}{ Site 2} & \multicolumn{4}{|l|}{ Site 3} \\
\hline & \multicolumn{2}{|l|}{ Fine } & \multicolumn{2}{|l|}{ Coarse } & \multicolumn{2}{|l|}{ Fine } & \multicolumn{2}{|l|}{ Coarse } & \multicolumn{2}{|l|}{ Fine } & \multicolumn{2}{|l|}{ Coarse } \\
\hline & Warm $^{\mathrm{a}}$ & Cold $^{\mathrm{b}}$ & Warm $^{\mathrm{a}}$ & Cold $^{\mathrm{b}}$ & Warm $^{\mathrm{a}}$ & Cold $^{\mathrm{b}}$ & Warm $^{\mathrm{a}}$ & Cold $^{\mathrm{b}}$ & Warm $^{\mathrm{a}}$ & Cold $^{\mathrm{b}}$ & Warm $^{\mathrm{a}}$ & Cold $^{\mathrm{b}}$ \\
\hline PM & 26.4 & 24.5 & 7.81 & 6.77 & 22.4 & 20.2 & 6.81 & 4.73 & 21.7 & 29.7 & 5.53 & 5.70 \\
\hline $\mathrm{Al}$ & 272 & 228 & 154 & 140 & 84 & 75 & 54 & 54 & 75 & 48 & 55 & 41 \\
\hline As & 2.0 & 3.9 & 0.040 & 0.24 & & & & & 3.5 & 6.9 & 0.048 & 0.25 \\
\hline $\mathrm{Ca}$ & 373 & 317 & 377 & 330 & 46 & 42 & 122 & 105 & 140 & 113 & 178 & 160 \\
\hline $\mathrm{Cd}$ & 1.1 & 2.2 & 0.044 & 0.18 & 0.22 & 0.95 & 0.009 & 0.027 & 1.1 & 3.3 & 0.026 & 0.23 \\
\hline Co & 0.19 & 0.23 & 0.065 & 0.084 & 0.040 & 0.039 & 0.016 & 0.018 & 0.046 & 0.069 & 0.028 & 0.026 \\
\hline $\mathrm{Cu}$ & 6.3 & 6.4 & 2.9 & 3.9 & $2.2^{\mathrm{c}}$ & $3.0^{c}$ & 1.1 & 1.1 & 4.7 & 7.0 & 2.7 & 2.9 \\
\hline $\mathrm{Fe}$ & 227 & 196 & 135 & 157 & 88 & 94 & 47 & 55 & 126 & 147 & 73 & 77 \\
\hline K & 144 & 219 & 50 & 59 & 81 & 117 & 34 & 24 & 91 & 273 & 31 & 31 \\
\hline $\mathrm{Li}$ & 0.343 & 0.344 & 0.143 & 0.137 & 0.071 & 0.056 & 0.045 & 0.040 & 0.069 & 0.067 & 0.042 & 0.029 \\
\hline $\mathrm{Mg}$ & 117 & 99 & 112 & 93 & 34 & 33 & 74 & 64 & 57 & 38 & 70 & 45 \\
\hline $\mathrm{Mn}$ & 9.1 & 10.7 & 4.8 & 7.9 & 3.3 & 4.3 & 1.5 & 1.5 & 3.7 & 6.0 & 1.8 & 2.0 \\
\hline $\mathrm{Na}$ & 195 & 217 & 169 & 165 & 140 & 173 & 422 & 339 & 91 & 99 & 144 & 71 \\
\hline $\mathrm{Ni}$ & 11.8 & 12.9 & 2.1 & 2.6 & $2.1^{\mathrm{c}}$ & $3.0^{c}$ & 0.17 & 0.48 & 1.1 & 2.2 & 0.22 & 0.41 \\
\hline $\mathrm{Pb}$ & 16 & 18 & 2.2 & 3.3 & $8.2^{\mathrm{c}}$ & $11.1^{\mathrm{c}}$ & 0.62 & 0.88 & 8.8 & 21 & 0.81 & 1.9 \\
\hline $\mathrm{Sr}$ & 1.22 & 0.97 & 0.96 & 0.84 & 0.45 & 0.53 & 0.64 & 0.64 & 0.64 & 0.44 & 0.57 & 0.41 \\
\hline V & 9.8 & 10.7 & 1.5 & 1.9 & 4.6 & 5.3 & 0.39 & 0.61 & 1.7 & 2.1 & 0.18 & 0.27 \\
\hline $\mathrm{Zn}$ & 43 & 55 & 9.1 & 23.6 & $20^{c}$ & $39^{c}$ & 3.8 & 6.0 & 20 & 58 & 1.9 & 9.9 \\
\hline
\end{tabular}

a April-September.

b October-March.

c Seasonal difference significant at 0.05 level.

from $50 \%(\mathrm{Ca})$ to $45 \%(\mathrm{Na}, \mathrm{Sr}$ ) at site 1 and from $57 \%$ (Ca) to $48 \%$ $(\mathrm{Sr})$ at site 3 . Yet at site 1 , which is affected by industrial and urban sources, about $50 \%$ of these elements was present in the fine fraction. Therefore, we can hypothesise a significant contribution of the anthropogenic emissions in addition to the natural sources.

\subsubsection{Elements ( $\mathrm{Cd}, \mathrm{Pb}, \mathrm{Ni}, \mathrm{V}, \mathrm{As})$}

These elements showed a large mode between 0.49 and $1.5 \mu \mathrm{m}$ at all sites; Cd, Ni, V and As also showed an additional mode for $d_{p}<0.49 \mu \mathrm{m}$ at site 1 which could be associated with the accumulation of particles probably related to emissions from local sources (Fig. 2 and Fig. B). As regards these elements both the enrichment factors and the dimensional distribution indicated a significant anthropogenic contribution indeed. The enrichment factor calculated by $\mathrm{Al}$ ranged between 72 for $\mathrm{V}$ and 3190 for $\mathrm{Cd}$ and, at site 1 , the fraction with an aerodynamic diameter $<0.49 \mu \mathrm{m}$ was the highest.

The percentages of these combustion-derived elements were very low in the coarse fraction, ranging from $4 \%(\mathrm{As})$ to $16 \%(\mathrm{Ni})$ at site 1 , from $3 \%(\mathrm{Cd})$ to $11 \%(\mathrm{Ni})$ at site 2 and from $3 \%(\mathrm{As})$ to $16 \%(\mathrm{Ni})$ at site 3 . High concentrations were found in the fine fraction $(<1.5 \mu \mathrm{m})$ with contribution rates ranging from $95 \%$ (As) to $77 \%(\mathrm{Ni})$ at site 1 , from $94 \%(\mathrm{As})$ to $74 \%(\mathrm{Ni})$ at site 3 and from $93 \%(\mathrm{Cd})$ to $82 \%(\mathrm{Ni})$ at site 2 . At all sites lead showed a homogeneous size distribution as far as concentrations are concerned. In spite of the fact that gasoline with lead additives was phased out in the Northern European countries during the period of this study, in many countries in Eastern and Southern Europe, it was still used in vehicles lacking catalytic converters (Allen et al., 2001; Karanasiou et al., 2007) and lead is present as an impurity of the gasoline. Measurements of isotopic composition of lead (Howearth et al., 2005) have shown a significant change in the radiogenic lead composition in comparison with the composition observed one decade before; the afore said observations emphasised that the fine particles transported by long-range mechanisms and coming from Eastern Europe can contribute to the total amount of lead particulates in the Venice Lagoon.

\subsubsection{Elements ( $\mathrm{Al}, \mathrm{Fe}, \mathrm{Mn}, \mathrm{Cu}, \mathrm{Zn}, \mathrm{Co}, \mathrm{K}$ )}

$\mathrm{Al}, \mathrm{Fe}, \mathrm{Mn}, \mathrm{Cu}, \mathrm{Zn}, \mathrm{Co}$ and $\mathrm{K}$ presented a bimodal distribution; the first at $0.95-1.5 \mu \mathrm{m}$ and the second at 3-10 $\mu \mathrm{m}$, in accord with multiple sources. However, during the cold season, the second mode was much reduced or absent for $\mathrm{Mn}, \mathrm{Cu}$ and $\mathrm{Zn}$ at site 2 . This indicates that this site is slightly affected by local crustal erosion especially in winter season, being anthropogenic sources predominant. Furthermore, during the cold season, the "long range" transport contribution to the content of $\mathrm{Mn}, \mathrm{Cu}$ and $\mathrm{Zn}$ in the atmosphere of the Venice Lagoon is remarkable. These size distributions are in tune with literature data from different geographical regions (Chan et al., 1997; Rizzio et al., 1999; Manoli et al., 2002; Wang et al., 2006).

The percentage of metals was lower in the coarse fraction than in the fine fraction. It ranges from $40 \%(\mathrm{Fe})$ to $23 \%(\mathrm{Zn})$ at site $1,40 \%(\mathrm{Al})$ to $14 \%(\mathrm{Zn})$ at site 2 and $44 \%(\mathrm{Al})$ to $14 \%(\mathrm{Zn})$ at site 3 . The metal content prevailed in the very fine fraction $(<1.5 \mu \mathrm{m})$ with contributions to $\mathrm{PM}_{10}$ ranging from $68 \%(\mathrm{~K}, \mathrm{Zn})$ to $46 \%(\mathrm{Fe})$ at site 1 , from $73 \%(\mathrm{Zn})$ to $40 \%(\mathrm{Al})$ at site 2 and from $77 \%(\mathrm{~K})$ to $37 \%(\mathrm{Al})$ at site 3 .

\subsection{Multivariate data analysis}

The data processing was performed using Statgraphics Centurion XVI. Only the chemical species with concentrations above the detection limit in more than $40 \%$ of the samples were included in the datasets; therefore, As, Ca and Li were excluded from the multivariate analysis. The data set from site 3 was excluded from the analysis because only five campaigns were carried out.

The principal component analysis (PCA) was performed in order to emphasise differences between site 1 and 2 on the basis of $\mathrm{PM}_{3}$ and/or $\mathrm{PM}_{3-10}$ composition. Fig. 3 shows the 27 object scores for the $\mathrm{PM}_{3}$ fraction and the variable loadings in the space of the first two principal components (the biplot for the $\mathrm{PM}_{3-10}$ is presented in Fig. C). For both $\mathrm{PM}_{3}$ and $\mathrm{PM}_{3-10}$, the first two principal components explained for more than $80 \%$ of the total variance and the first principal component differentiated the two sites. As almost all variables had similar weights on the first PC, we hypothesised this component being related to the elemental concentration; indeed, the two sites differed in almost all metal concentrations. The biplot of the coarse fraction showed the relevance of $\mathrm{Na}$ in the coarse fraction of the site 2 samples derived from marine aerosol.

Factor analysis was used to explore the relationship between variables using a Varimax rotation procedure to maximise the explained variance. Table 3 presents the factor loading obtained 


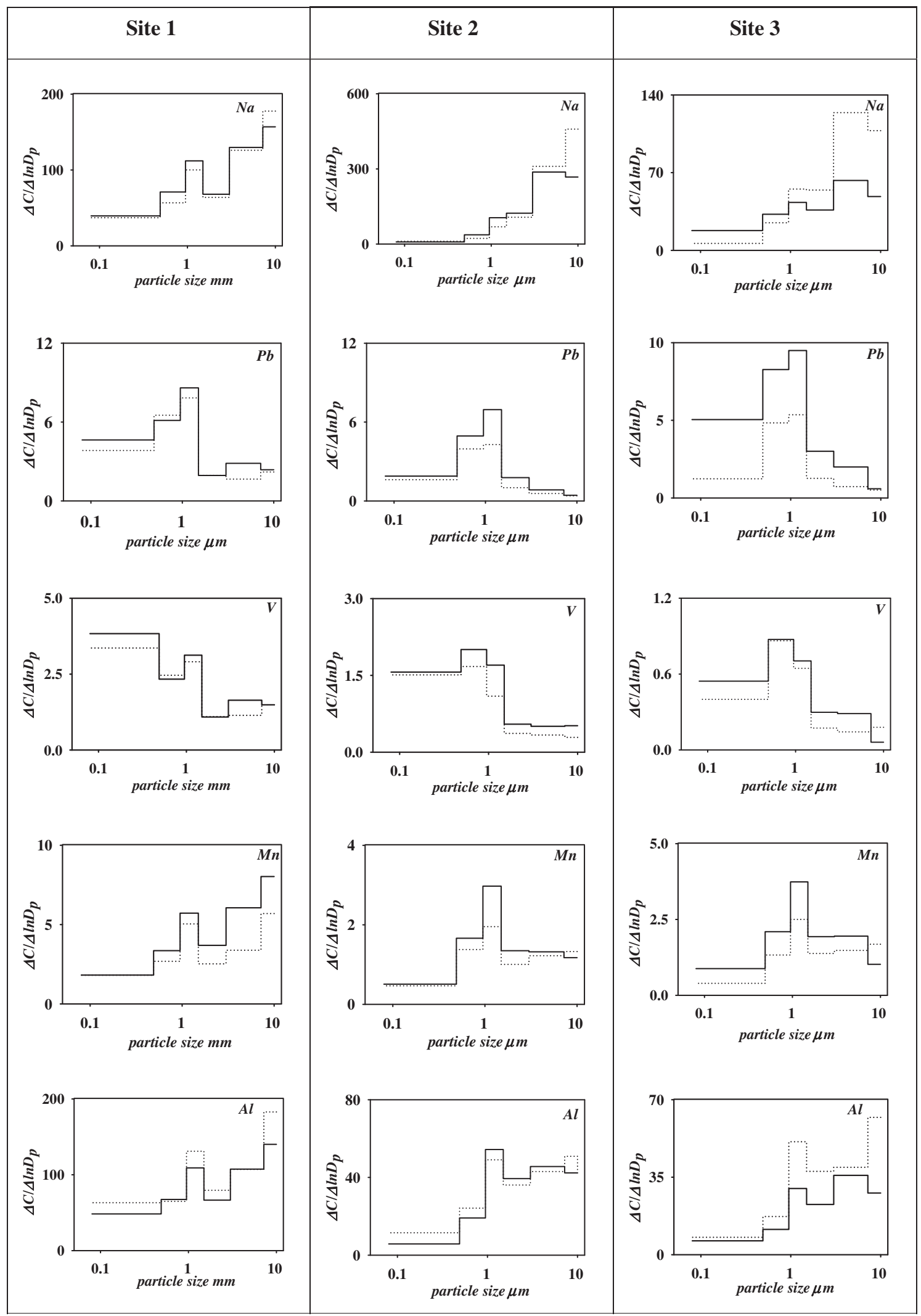

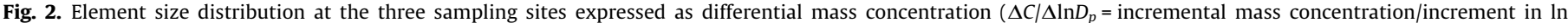
particle diameter) in winter (--) and summer $(\ldots \ldots \ldots \ldots)$; concentration in $\mathrm{ng} \mathrm{m}^{-3}$.

for the fine aerosol fractions from site 2 . Four factors were obtained with eigenvalues $>1$, summing $80 \%$ of the total variance in the fine particle data set.
The first factor, accounting for $25 \%$ of the total variance, presented highest loading for $\mathrm{Pb}, \mathrm{K}, \mathrm{Mn}, \mathrm{Cu}$ and $\mathrm{Zn}$. These elements have been reported as being predominant in road dust, deriving 


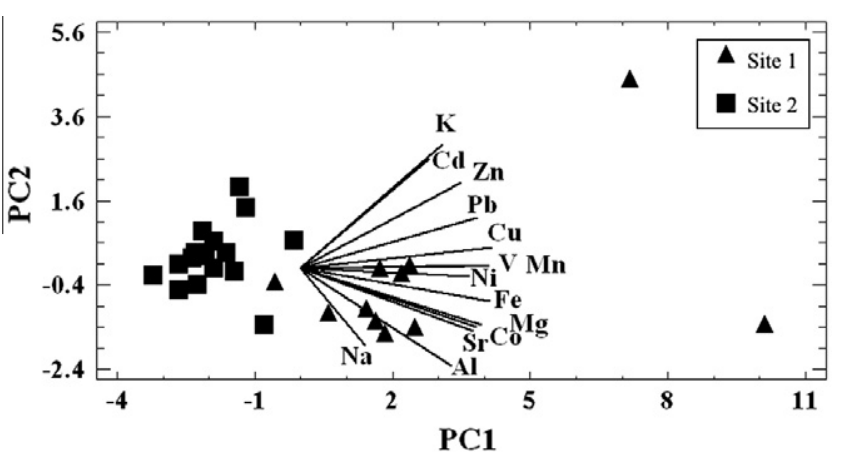

Fig. 3. PCA biplot relative to the $\mathrm{PM}_{3}$ elemental composition of the sites 1 and 2 , in the plane defined by the first two components.

Table 3

Variable loadings in the factors obtained by Varimax rotation for the $\mathrm{PM}_{3}$ at site 2 .

\begin{tabular}{lllll}
\hline Element & Factor 1 & Factor 2 & Factor 3 & Factor 4 \\
\hline $\mathrm{Al}$ & -0.064 & 0.023 & $\mathbf{0 . 8 1 7}$ & -0.185 \\
$\mathrm{Cd}$ & 0.532 & $\mathbf{0 . 6 0 3}$ & -0.279 & -0.397 \\
$\mathrm{Co}$ & 0.145 & $-\mathbf{0 . 8 3 1}$ & 0.146 & -0.021 \\
$\mathrm{Cu}$ & $\mathbf{0 . 7 8 5}$ & 0.022 & 0.089 & 0.253 \\
$\mathrm{Fe}$ & 0.452 & -0.021 & $\mathbf{0 . 8 3 3}$ & 0.128 \\
$\mathrm{~K}$ & $\mathbf{0 . 7 1 2}$ & -0.312 & 0.105 & -0.080 \\
$\mathrm{Mg}$ & 0.090 & 0.203 & $\mathbf{0 . 9 0 4}$ & 0.002 \\
$\mathrm{Mn}$ & $\mathbf{0 . 7 2 3}$ & -0.027 & $\mathbf{0 . 6 3 2}$ & 0.148 \\
$\mathrm{Na}$ & 0.027 & $\mathbf{0 . 7 7 0}$ & 0.519 & 0.065 \\
$\mathrm{Ni}$ & 0.324 & 0.277 & -0.027 & $\mathbf{0 . 8 5 3}$ \\
$\mathrm{Pb}$ & $\mathbf{0 . 6 5 5}$ & 0.096 & 0.367 & 0.187 \\
$\mathrm{Sr}$ & 0.154 & $\mathbf{0 . 8 2 3}$ & 0.432 & -0.055 \\
$\mathrm{~V}$ & -0.102 & -0.221 & -0.060 & $\mathbf{0 . 8 3 6}$ \\
$\mathrm{Zn}$ & $\mathbf{0 . 8 8 0}$ & 0.278 & -0.103 & -0.209 \\
\hline
\end{tabular}

In bold loadings higher than $|0.6|$.

from soil and other sources, such as tyre wear (Zn), brake drum abrasion (Fe), brake linings and diesel engines ( $\mathrm{Cu}$ ) (Weckwerth, 2001; Manoli et al., 2002; Birmili et al., 2006). Moreover, it is well known that vehicle emissions are sources of $\mathrm{Pb}$. Therefore, we have hypothesised that this factor describes vehicular emissions and road dust resuspension. The second factor, accounting for $19.1 \%$ of the variance, has been associated with marine aerosol because of the high loading of $\mathrm{Na}$ and $\mathrm{Sr}(0.8)$. The third factor, accounting for $23.6 \%$ of the total variance, is characterised by high loading of $\mathrm{Mg}, \mathrm{Fe}, \mathrm{Al}$ and $\mathrm{Mn}$, therefore it can be associated with crustal contribution. The fourth factor, accounting for $13.0 \%$ of the total variance, presented high loading for $\mathrm{Ni}$ and $\mathrm{V}$. Vanadium is generally considered a marker of oil combustion (Pacyna and Pacyna, 2001 ) therefore this component can be associated with static combustion sources and "long range" transport; nevertheless, ship emissions from local maritime traffic cannot be excluded according to different studies carried out in the Venice Lagoon, (Rampazzo et al., 2008; Stortini et al., 2009).

Four factors were obtained for the coarse particles data set, which explained $84 \%$ of the total variance and showed a loading pattern similar to the fine particle data set. Remarkable differences were observed in the case of $\mathrm{Pb}$ and $\mathrm{Mg}$, which presented high loading on the factors associated with oil combustion and marine aerosol, respectively.

Three factors were obtained with eigenvalues $>1$, summing $87 \%$ of the variance, for the fine data set from site 1 (Table 4). The first factor, accounting for $40 \%$ of the total variance, was characterised by high loading for $\mathrm{Cu}, \mathrm{Mn}, \mathrm{Cd}, \mathrm{Zn}, \mathrm{Pb}, \mathrm{Ni}, \mathrm{V}$ and $\mathrm{K}$. This can be interpreted as incorporating traffic and road dust sources as well
Table 4

Variable loadings in the factors obtained by Varimax rotation for the $\mathrm{PM}_{3}$ at site 1 .

\begin{tabular}{llll}
\hline Element & Factor 1 & Factor 2 & Factor 3 \\
\hline $\mathrm{Al}$ & -0.202 & $\mathbf{0 . 8 5 0}$ & -0.097 \\
$\mathrm{Cd}$ & $\mathbf{0 . 7 5 9}$ & 0.052 & 0.310 \\
$\mathrm{Co}$ & 0.232 & $\mathbf{0 . 9 0 6}$ & -0.178 \\
$\mathrm{Cu}$ & $\mathbf{0 . 7 0 5}$ & 0.649 & 0.226 \\
$\mathrm{Fe}$ & 0.418 & 0.887 & 0.141 \\
$\mathrm{~K}$ & $\mathbf{0 . 9 2 4}$ & 0.033 & 0.207 \\
$\mathrm{Mg}$ & 0.220 & $\mathbf{0 . 9 1 7}$ & 0.155 \\
$\mathrm{Mn}$ & 0.713 & 0.578 & -0.032 \\
$\mathrm{Na}$ & -0.028 & -0.012 & $-\mathbf{0 . 9 2 0}$ \\
$\mathrm{Ni}$ & $\mathbf{0 . 8 6 3}$ & 0.014 & -0.293 \\
$\mathrm{~Pb}$ & $\mathbf{0 . 8 2 1}$ & 0.469 & 0.030 \\
$\mathrm{Sr}$ & 0.242 & $\mathbf{0 . 9 1 3}$ & 0.039 \\
$\mathrm{~V}$ & $\mathbf{0 . 8 8 6}$ & 0.216 & -0.209 \\
$\mathrm{Zn}$ & $\mathbf{0 . 7 6 3}$ & 0.582 & 0.246 \\
\hline
\end{tabular}

In bold loadings higher than $|0.6|$.

as industrial emissions. The second factor, accounting for $38 \%$ of the total variance and showing the highest loadings for $\mathrm{Al}, \mathrm{Fe}, \mathrm{Co}$, $\mathrm{Mg}$, $\mathrm{Sr}$ and $\mathrm{Mn}$, has been associated with crustal material. The third factor accounting for $9.4 \%$ of the total variance, is associated with marine sources as the Na presented the highest loading. Three factors were also obtained for the coarse particles data set, which are the reason for $94 \%$ of the total variance and showed a loading pattern similar to the fine particle data set one.

\section{Conclusions}

Atmospheric particulate samples were collected for more than 1 year at three sites in the Venice Lagoon to examine size distribution and seasonal variability of the particulate mass as well as the concentration of selected elements. The value of $\mathrm{PM}_{10}$ content, separately identified in fine and coarse fractions, is in tune with values found in North European towns; such content was uniformly distributed in the Lagoon area, with an evident predominance of the fine fraction (diameter $<3 \mu \mathrm{m}$ ). The size distributions at site 1 and site 2 appeared bimodal in both winter and summer seasons, but at site 3 , the distribution of PM was unimodal in the cold season and bimodal in the warm one.

The mean element concentrations in $\mathrm{PM}_{10}$ were similar at sites 2 and 3 and in line with values reported for urban-industrial sites in Northern and Central Europe. The highest $\mathrm{PM}_{10}$ metal concentration for almost all elements was found at site 1, downwind from the industrial area of Porto Marghera and the Venice mainland urban area (Mestre).

Significant seasonal variations were observed at site 1 and site 3 for $\mathrm{Ni}, \mathrm{Cu}, \mathrm{Zn}$ and $\mathrm{Pb}$ in the fine fraction, which were ascribable to the higher contribution of fossil fuel combustion for heating and to the increase in traffic in the cold season, as well as to winter frequent thermal inversions at ground level.

The similarity in size distribution at all sites allowed the identification of three different element behaviour types: (a) associated to coarse particles (Na, $\mathrm{Mg}, \mathrm{Sr}, \mathrm{Ca}$ ); (b) associated to fine particles $(\mathrm{Cd}, \mathrm{Pb}, \mathrm{Ni}, \mathrm{V}, \mathrm{As})$ and (c) with multi-modes distribution spread throughout the entire size range ( $\mathrm{Fe}, \mathrm{Zn}, \mathrm{Cu}, \mathrm{Co}, \mathrm{Mn})$.

Factor analysis was performed on fine and coarse aerosol data to investigate the relationship between the inorganic elements and to identify their origin. A similar trend was observed for the coarse and fine particle data sets from sites 1 and 2 . At site 2 four sources were identified according to the factors: vehicular and road dust, crustal sources, marine sources and fuel oil combustion emissions. At site 1 , only three factors were significantly accounting for vehicular-road dust and industrial, crustal and marine emissions as sources. Multivariate data analysis and assessment on similarity in the size distribution drew on analogous conclusions. 


\section{Acknowledgements}

This study was supported by CORILA within the Project 'Role of aerosol and secondary pollution in the chemical contamination of the Lagoon of Venice'. We thank the Ente Zona Marghera and ARPAV for sampling support and V. Zampieri for technical support.

\section{Appendix A. Supplementary material}

Supplementary data associated with this article can be found, in the online version, at doi:10.1016/j.chemosphere.2011.09.045.

\section{References}

Allen, A.G., Nemitz, E., Shi, J.P., Harrison, R.M., Greenwood, J.C., 2001. Size distributions of trace metals in atmospheric aerosol in the United Kingdom. Atmos. Environ. 35, 4581-4591.

Bini, C., 2008. Fate of trace elements in the Venice Lagoon watershed and conterminous areas (Italy). In: Sánchez, M.L. (Ed.), Causes and effects of heavy metal pollution. Nova Science Publishers Inc., pp. 137-171.

Birmili, W., Allen, A.G., Bary, F., Harrison, R.M., 2006. Trace metal concentrations and water solubility in size-fractionated atmospheric particles and influence of road traffic. Environ. Sci. Technol. 40, 1144-1153.

Chan, Y.C., Simpson, R.W., McTainsh, G.H., Vowles, P.D., Cohen, D.D., Bailey, G.M., 1997. Characterisation of chemical species in $\mathrm{PM}_{2.5}$ and $\mathrm{PM}_{10}$ aerosols in Brisbane, Australia. Atmos. Environ 31, 3773-3785.

Chan, Y.C., Vowles, P.D., McTainsh, G.H., Simpson, R.W., Cohen, D.D., Bailey, G.M. McOrist, G.D., 2000. Characterisation and source identification of PM10 aerosol samples collected with a high volume cascade impactor in Brisbane (Australia). Sci. Total Environ. 262, 5-19.

Donaldson, K., Brown, D.M., Mitchell, C., Dineva, M., Beswick, P.H., Gilmour, P., MacNee, W., 1997. Free radical activity of $\mathrm{PM}_{10}$. Iron-mediated generation of hydroxyl radicals. Environ. Health Persp. 105, 1285-1290.

Gambaro, A., Manodori, L., Moret, I., Capodaglio, G., Cescon, P., 2004. Transport of gas-phase polycyclic aromatic hydrocarbons to the Venice Lagoon. Environ. Sci. Technol. 38, 5357-5364.

Gambaro, A., Manodori, L., Toscano, G., Contini, D., Donateo, A., Belosi, F., Prodi, F., Cescon, P., 2007. PAHs and trace elements in PM2.5 at the Venice Lagoon. Ann. Chim.-Rome 97, 343-358.

Heal, M.R., Hibbs, L.R., Agius, R.M., Berland, I.J., 2005. Total and water-soluble metal content of urban background PM10, PM2.5 and black smoke in Edinburgh, UK. Atmos. Environ 39, 1417-1430.

Howearth, L., Rosman, K.J.R., Gambaro, A., Toscano, G., Capodaglio, G., 2005. Isotopic composition and concentration of lead on aerosols in the region of Venice. In: Campostrini, P. (Ed.), Scientific Research and Safeguarding of Venice, vol. III. CORILA, Venice, pp. 295-308.

Hueglin, C., Gehrig, R., Baltensperger, U., Gysel, M., Monn, C., Vonmont, H., 2005. Chemical characterisation of $\mathrm{PM}_{2.5}, \mathrm{PM}_{10}$ and coarse particles at urban, nearcity and rural sites in Switzerland. Atmos. Environ 39, 637-651.

Johansson, C., Norman, M., Burman, L., 2009. Road traffic emission factors for heavy metals. Atmos. Environ. 43, 4681-4688.

Karanasiou, A.A., Sitaras, I.E., Siskos, P.A., Eleftheriadis, K., 2007. Size distribution and sources of trace metals and n-alkanes in the Athens urban aerosol during summer. Atmos. Environ. 41, 2368-2381.

Lee, D.S., Garland, J.A., Fox, A.A., 1994. Atmospheric Concentrations of TraceElements in Urban Areas of the United-Kingdom. Atmos. Environ. 28, 26912713.

Makkonen, U., Hellen, H., Anttila, P., Ferm, M., 2010. Size distribution and chemical composition of airborne particles in south-eastern Finland during different seasons and wildfire episodes in 2006. Sci. Total Environ. 408, 644-651.
Manodori, L., Gambaro, A., Moret, I., Capodaglio, G., Cains, W.R.L., Cescon, P., 2006. Seasonal evolution of gas-phase PCB concentrations in the Venice Lagoon area. Chemosphere 62, 449-458.

Manoli, E., Voutsa, D., Samara, C., 2002. Chemical characterization and source identification/apportionment of fine and coarse air particles in Thessaloniki. Greece. Atmos. Environ. 36, 949-961.

Mantovan, I., Varga, A., Rampazzo, G., Barbante, C., 2004. Transport of inorganic elements by aerosol. In: Campostrini, P. (Ed.), Scientific Research and Safeguarding of Venice, Vol. II. CORILA, pp. 297-302.

Marcazzan, G.M., Vaccaro, S., Valli, G., Vecchi, R., 2001. Characterisation of $\mathrm{PM}_{10}$ and $\mathrm{PM}_{2.5}$ particulate matter in the ambient air of Milan (Italy). Atmos. Environ 35 4639-4650.

Moreno, T., Querol, X., Alastuey, A., Viana, M., Salvador, P., de la Campa, A.S. Artinano, B., de la Rosa, J., Gibbons, W., 2006. Variations in atmospheric PM trace metal content in Spanish towns: Illustrating the chemical complexity of the inorganic urban aerosol cocktail. Atmos. Environ. 40, 6791-6803.

Nriagu, G.O., Pacyna, J.M., 1988. Quantitative assessment of worldwide contamination of air, water and soils by trace metals. Nature 333, 134-139.

Pacyna, J.M., Pacyna, E.G., 2001. An assessment of global and regional emissions of trace metals to the atmosphere from anthropogenic sources worldwide. Environ. Rev. 9, 269-298.

Pey, J., Querol, X., Alastuey, A., 2009. Variations of levels and composition of PM(10) and $\mathrm{PM}(2.5)$ at an insular site in the Western Mediterranean: Atmos. Res 94, 285-299.

Pope III, C.A., 1996. Adverse health effects of air pollutants in a nonsmoking population. Toxicology $111,149-155$.

Rampazzo, G., Masiol, M., Visin, F., Rampado, E., Pavoni, B., 2008. Geochemical characterization of $\mathrm{PM}_{10}$ emitted by glass factories in Murano, Venice (Italy). Chemosphere 71, 2068-2075.

Rapporto ambientale d'area di Porto Marghera, Bilancio Ambientale 1998-2007. Regione Veneto, Agenzia Regionale per la Prevenzione e Protezione Ambientale del Veneto, Ente della Zona Industriale di Porto Marghera.

Rizzio, E., Giaveri, G., Arginelli, D., Gini, L., Profumo, A., Gallorini, M., 1999. Trace elements total content and particle sizes distribution in the air particulate matter of a rural-residential area in north Italy investigated by instrumental neutron activation analysis. Sci. Total Environ. 226, 47-56.

Salma, L., Maenhaut, W., Zaray, G., 2002. Comparative study of element mass size distribution in urban atmospheric aerosol. Aerosol Sci. 33, 339-356.

Schwartz, J., Dockery, D.W., Neas, L.M., 1996. Is daily mortality associated specifically with fine particles? J. Air Waste Manage. Ass. 46, 927-939.

Stortini, A.M., Freda, A., Cesari, D., Cairns, W.R.L., Contini, D., Barbante, C., Prodi, F., Cescon, P., Gambaro, A., 2009. An evaluation of the $\mathrm{PM}_{2.5}$ trace elementa composition in the Venice Lagoon area and an analysis of the possible sources. Atmos. Environ 43, 6296-6304.

Toscano, G., Gambaro, A., Capodaglio, G., Cairns, W.R.L., Cescon, P., 2009 Assessment of a procedure to determine trace and major elements in atmospheric aerosol. J. Environ. Monitor. 11, 193-199.

Vercauteren, J., Matheeussen, C., Wauters, E., Roekens, E., van Grieken, R., Krata, A. Makarovska, Y., Maenhaut, W., Chi, X., Geypens, B., 2011. Chemkar $\mathrm{PM}_{10}$ : An extensive look at the local differences in chemical composition of $\mathrm{PM}_{10}$ in Flanders. Belgium. Atmos. Environ. 45, 108-116.

Viana, M., Maenhaut, W., Chi, X., Querol, X., Alastuey, A., 2007. Comparative chemical mass closure of fine and coarse aerosols at twosites in south and west Europe: Implications for EU air pollution policies. Atmos. Environ. 41, 315-326.

Voutsa, D., Samara, C., Kouimtzis, T., Ochsenkuhn, K., 2002. Elemental composition of airborne particulate matter in the multi-impacted urban area of Thessaloniki. Greece. Atmos. Environ. 36, 4453-4462.

Wang, X.L., Sato, T., Xing, B.S., 2006. Size distribution and anthropogenic sources apportionment of airborne trace metals in Kanazawa, Japan. Chemosphere 65, 2440-2448.

Weckwerth, G., 2001. Verification of traffic emitted aerosol components in the ambient air of Cologne (Germany). Atmos. Environ. 35, 5525-5536. 